\title{
Community of Inquiry for Students' Autonomy in English Language Learning: A Case of Philippines High School
}

\author{
Alqy Novia Rachman ${ }^{1}$, Ana Maghfiroh², Diyah Atiek Mustikawati ${ }^{3}$, Niken Reti \\ Indriastuti 4 \\ ${ }^{1}$ University of Muhammadiyah Ponorogo, Indonesia.e-mail: alqynov35@gmail.com \\ 2 Yogyakarta State University, Indonesia.e-mail: ana.maghfiroh2016@student.uny.ac.id \\ 3University of Muhammadiyah Ponorogo, Indonesia.e-mail:diyah_mustikawati@yahoo.co.od \\ 4University of Muhammadiyah Ponorogo, Indonesia.e-mail:nikenreti@gmail.com
}

\begin{tabular}{|c|c|}
\hline ARTICLE INFO & ABSTRACT \\
\hline $\begin{array}{l}\text { Keywords: } \\
\text { community of inquiry, } \\
\text { autonomous learner, } \\
\text { language learning, } \\
\text { collaborative learning }\end{array}$ & $\begin{array}{l}\text { There were many researchers bring out the topic of the community of inquiry } \\
\text { (Col) in education but there were still few teachers who were aware of the } \\
\text { importance of Col and how to implement Col into learning. This study was, } \\
\text { then, aimed at finding out (1) how the community of inquiry was explicitly } \\
\text { applied to English language learning, as well as (2) the impact of the } \\
\text { community of inquiry to promote students' autonomous learning. This } \\
\text { research was a case study. The researcher used observation and interview as } \\
\text { the research instrument. The subjects were the seventh and eighth-grade } \\
\text { students of Pangasinan State University (PSU) Integrated High School, } \\
\text { Philippines. The sample has consisted of 101 participants from three classes: } \\
\text { th-grade Malakas and Maganda, and 8th-grade Matapat. The finding } \\
\text { showed that Col had been implemented during the English language teaching } \\
\text { and learning process. Group activity or collaborative task was mostly used to } \\
\text { engage students to learn and work in a community. In language acquisition, } \\
\text { Col was supposed to provide students with not only cognitive intelligence but } \\
\text { also much-needed social intelligence. Therefore, the Col approach has been } \\
\text { considered to be effective in language teaching activities for secondary } \\
\text { education students to enhance students'autonomous learning. }\end{array}$ \\
\hline \multicolumn{2}{|c|}{$\begin{array}{l}\text { How to cite: } \\
\text { Rachman, A.N., Maghfroh, A., Mustikawati, D., Indriastuti, N.. (2021). Community of Inquiry for Students } \\
\text { Autonomy in English Language Learning: A Case of Philippines High School. Indonesian Journal of English } \\
\text { Language Teaching and Applied Linguistics, } 6(1), 61-72\end{array}$} \\
\hline
\end{tabular}

\section{Introduction}

Nowadays, issues in English language education are going to be complicated. Some primary problems in English language education in Asia were highlighted by survey results such as (1) Sociocultural or linguistic context (2) English language education policies (3) Class size and hours (4) Curriculum and learning contents (5) Teaching methods and materials (6) Students (7) Teachers (8) Parents (Choi \& Lee, 2008). Furthermore, some students from Asia (Vietnam, 
Thailand, and Indonesia) who studied in Australia agreed that English lectures concerned a lot on grammar in English foreign language (EFL) classrooms. The students were learning English technically and not pragmatically. Other skills such as speaking, pronunciation, listening, or writing was also taught, but not effectively (Cao, 2011). For those, teachers need some fundamental matters to solve the above-mentioned critical problems and to study the English language effectively. It means students demand an appropriate environment to practice their ability, a good mentor to consult their problem, and a resourceful self for great evolution. The students need a Community of Inquiry (Col) to thrive in a knowledge-driven society.

The community of inquiry approach is one of the appropriate pedagogy for thinking in education (Garrison, 2016). The community of inquiry attempts to involve the participants, both teachers, and students, in engaging with each other to build a community of inquiry to understand the world around them. A study result showed that the group model was very successful in involving students in studying and discussing concepts, developing critical thinking, effective, and collaborative skills (Preece \& Bularafa, 2015). The use of the inquiry culture as a solution to an increasing range of issues faced in contemporary education can give rise to the assumption that almost everything can be achieved by the Col (Šimenc, 2008).

Such inline, one research indicated that the approach of the community of inquiry has great potential to benefit the English language skills of learners. It combined listening and speaking abilities, with learners having the opportunity to practice their listening and speaking in a community of inquiry through expressing their opinions. Col has the potential to increase the confidence of learners to listen effectively (Preece \& Bularafa, 2015). Then, Col in Language learning made students feel at ease to learn and engage with one another. Because of their emotional connection, they were willing to share their knowledge with the teacher and other members without fear or reluctance. They gained new knowledge and assisted one another in gaining new information(Ginting, 2017). The framework of a community of inquiry appears to be well-suited to the study of autonomous groups(Goldberg \& Welsh, 2009). Moreover, Collaborative action is a great tool for developing autonomous learning as well as for such analysis(Arnó-Macià, 2016).

This case study was conducted at Pangasinan State University Integrated High School, Philippines. The researcher chooses 10 students for interview from classes 7 and 8 randomly as the sample of the whole population because the teacher had implemented Col in her teaching. Regarding the importance of a Col to be engaged by the school and university, this article was written to answering these research questions:

1. How the community of inquiry is explicitly applied to English language learning classrooms?

2. How does the role of the community of inquiry promote the autonomy of students in learning English?

\section{Literature Review}

\subsection{Col Framework}

In 2000, Garrison et al. founded the Community of Inquiry (Col) framework (Kilis \& Yıldırım, 2018). Col is a brief and representative framework that defines a collaborative and positive approach to thought and learning (Garrison, 2016). It is an effort to understand the social, 
technological, and pedagogical processes that contribute to the construction of collaborative knowledge (Shea \& Bidjerano, 2009). Col offers a theoretical framework in which the influence of a purposeful learning environment on the individual's cognitive processes can be studied and understood (Garrison, 2016). In sum, Col is a brief and representative structure that describes a thinking and learning approach that is collaborative and constructive.

Initially, the Col framework was created to provide an orderly definition and methodology for the study and practice of online learning. Not just online learning, it is a general framework originating from and applied explicitly to higher education (Garrison, 2016). The framework articulates the behaviors and processes needed to foster the construction of knowledge by fostering different types of "presence" including teaching, social, and cognitive presence (Shea \& Bidjerano, 2009).

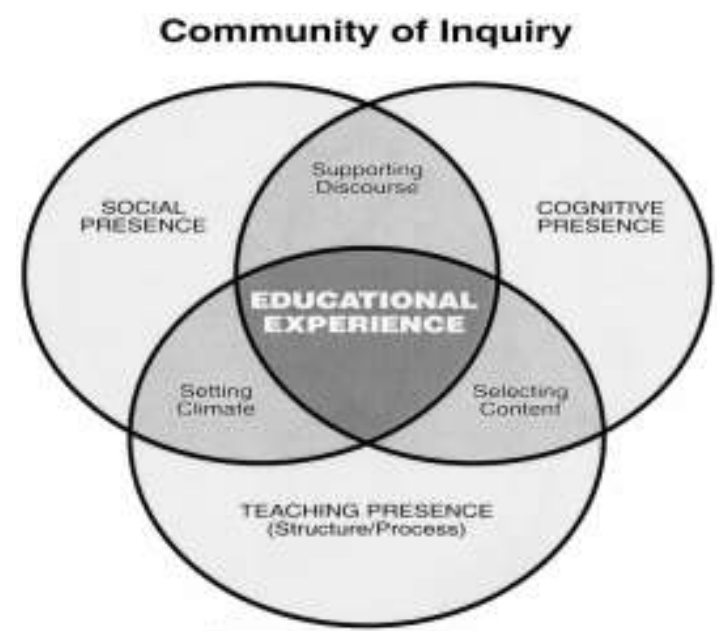

Figure 1. The Community of Inquiry Framework (Garrison et al., 2000)

The first core element is cognitive presence. In analytical thought, cognitive presence is characterized in an investigative culture as the discovery, creation, resolution, and confirmation of understanding through cooperation and reflection (Garrison, 2011). If a social presence is the soul of an inquiry community, cognitive presence is the core of an inquiry community. From an instructional background, a primary task of cognitive presence is to make sure that students pass through the investigative processes on time (Garrison, 2016). The second term is teaching presence. The teaching presence is the basis for developing an online inquiry group. It acts as the mediating and regulating aspect of Col and, therefore, it is necessary to promote social presence, which in turn promotes cognitive presence. Then, social presence is the third core element. Emotions are inseparably related to the drive and persistence of activities and, therefore, to a critical investigation (Kilis \& Yıldırım, 2018). The impact of social presence is rooted in the belief that a research group constitutes a collective, cohort-based approach to thought and learning (a social constructivist paradigm) (Garrison, 2016). In short, all of them get their specification, moreover, some of them is becoming superior. On the contrary, these three aspects must be together to become a whole unity towards one goal.

To conclude, the Community of Inquiry process aimed to give a new theoretical perspective of this nature. About spoken language, it also drew on perspectives from the fields of linguistics and communication concerning relevant features of text-based communication (Garrison et al., 2010). The Col system has the value of allowing one to understand collective 
reasoning and learning. When the Col paradigm was first developed, it is important to focus on inquiry as the mechanism to achieve deep and substantive learning (Garrison, 2016). The goal of the Community of Inquiry framework was to provide this kind of new logical standpoint. The Col framework has the importance of helping people to understand collaborative thought and understanding.

\subsection{Col and Learner's Autonomy}

Autonomy is the willingness of language learners to use effective methods to control their learning to reach the desired target of language proficiency. Some of the strategies chosen by autonomous language learners may include: a) identifying an effective technique for learning, b) setting learning objectives, c) deciding on the content and speed of learning, d) overseeing the learning process, and e) critically evaluating learning achievements (Murray et al., 2017). Identically, Learner autonomy thus directly focuses on English language learning being an independent learner however it is not only confined within a particular method and the perspective of individualism (Pokhrel, 2016). It could be concluded that the autonomy of learners is the readiness of language learners to use efficient methods to monitor their learning.

As it contributes to the evaluation of learning-related behaviors and attitudes, learners' considerations of their degree of autonomy are essential. It also encourages teachers to steer their learners in the classroom towards higher engagement(Valizadeh, 2016). Learner autonomy is a major manifestation of student-centric education in TEFL contexts. The key task of educators is to serve as facilitators, as guides on the side, from a student centre perspective. Student-centered educators appreciate that learners monitor their learning in the final analysis (Jacobs \& Shan, 2015). Teachers in TEFL contexts need to concentrate on student-centered education and to pay attention to student's autonomy because a significant manifestation of student-centric education is learner autonomy.

The Col approach has the potential to increase the confidence of learners (Preece \& Bularafa, 2015). Students may become less dependent on teachers by interacting with other people. Student teamwork can lead to superior results on a wide range of cognitive and affective factors, including accomplishment, reasoning capacity, interethnic relationships, school liking, and self-esteem(Jacobs \& Shan, 2015). One of the most effective ways to include students in language learning is through collaborative learning, which is excellent in developing students' learning autonomy and language awareness(Feri \& Erlinda, 2012). Inasmuch as learning is a social enterprise, forcing students to complete the given work in collaboration with others in the classroom constitutes an effort to highlight the social nature of learning and greatly enhances learning autonomy due to students' dependency in solving problems(Ardi, 2007). Equally, by communicating with other people, students can become less dependent on teachers. Student teamwork on a broad range of cognitive and affective variables will lead to superior performance.

\section{Research Methodology}

\subsection{Participants}

A case study was the design of this research. In its natural context, it includes an in-depth analysis of instances of a phenomenon by conveying the viewpoints of both the researchers and the participants and using methods to assess the validity and applicability of its results 
(Gall et al., 2014). This approach helped researchers to examine dynamic real-life events in which various sources of evidence have been used. Case studies are very useful where a particular problem or situation needs to be understood in great detail, and where knowledgerich cases can be found (Mohd Noor, 2008). One of the study's benefits was that individual teacher voices were given weight, which is typically underestimated in quantitative approaches aimed for applicability. The researcher's perspective helped to a deeper comprehension of the case and allowed for valuable perspectives to develop. The fact that the results cannot be applied is a fundamental weakness of this methodology. The findings are primarily applicable to the sample adopted for this research (Madalińska-Michalak \& Bavli, 2018). Therefore, this study will use the case study design popularized by Gall, et al (2014) to produce detailed and accurate research results.

The respondents of this research were the students of classes 7 and 8 and the teachers of Pangasinan State University (PSU) Integrated School High School, Philippines. The amount sample has consisted of three classes with 10 students' which are $7^{\text {th }}$ grade of Malakas and Maganda, and $8^{\text {th }}$ grade of Matapat, and 3 (three) English teachers. The researcher uses a random sample to conduct the interview.

\subsection{Instruments}

Observation and document analysis techniques were used in this research. Furthermore, the researcher not only became the one who took a note but also became a participant observer as a pre-service teacher. On the other hand, the researcher also took field-note, videos, and some documentations during the implementation of Col in English Language class. Then, interviews with three of teacher and 10 of students from PSU Integrated High School was also conducted to create a better result.

\subsection{Data Analysis Procedures}

To analyze the results, reflective analysis requires case study to rely principally on their intuition and personal judgment. Therefore, the results are representative both in the sense that represented by the conceptual context of the individual researcher who conducted the study and in the sense that emerged by a deep and intensely personal process of pondering a phenomenon (Gall et al., 2014).

\section{Findings}

\subsection{The Result of the Teachers' Interview}

Question 1: Have you ever heard about the Community of Inquiry?

Teacher A said that she heard about Col when she followed a seminar in 2019 before the Covid-19 pandemic occurred, but it did not delve deeper into the material of Col. Although she never took a deep understanding of it, she was familiar with the Col issue. Meanwhile, teacher B said that she gained an understanding of Col while he was learning about some alternative approaches/methods in English learning. In other statements, teacher $\mathrm{C}$ said that she learned about the community of inquiry when she was in a college as she was a fresh graduate. Then, she tried to implement the framework of Col when she was practicing as a teacher. 
Question 2: Have you ever grouped your students in learning?

Based on the teacher's experiences, when Teacher A handled junior and senior high school, most of the time, she did group or pair activities. The effectiveness of group activities depended on students' grades or levels. Sometimes, those kinds of activities did not impactfully on the senior high school level. Such inline, Base on teacher B's experiences, she uses group activity when speaking learning taken place. Speaking in English is not just a theory, but requires practice, one of which is to do pair or group activities. some students who are still shy may be a little late to join this activity, but over time they will get used to it and their confidence levels will gradually increase. Then, Base on teacher C's experiences, she does not use a group activity, but she uses a pair activity. She uses it when literature class.

Question 3: What was the purpose of your grouping of students?

According to teacher A's perspective, the purpose of group activity was to gain solid teamwork between students. It also let them build an independent group of learning between students in a group. Sometimes, some students could learn if they were in a group or teamwork. Besides, students could make a social experience during group activities. This matter enhanced the prove that group activity absolutely works that way. Meanwhile, from teacher B's point of view, the purpose of this activity is nothing but to train students' confidence to interact with others. however, to do this activity, teachers must always accompany students so that the development of their communication skills remains controlled. By making them in a pair group, teacher $C$ said that the students could discuss and exchange the information about literature together. As we know, literature material has a complicated point if it is based on personal identity. Therefore, the suggestions from friend nest to the students is needed for a better point of view.

Question 4: To what extent did the grouping technique affect students' learning independence?

Teachers A and B had the same answer. The extend of students' group activities toward students' autonomous learning were still dependent on the characteristic of students in the learning process. Some students could study within a group, but some students could only work individually. Group activity or collaborative activity is one strategy to engage students in various collaborative activities and to get students' autonomous learning. It was because one important goal of the teaching and learning process is to develop students' autonomous learning which meant that students should have the ability to control and manage their own learning. Students had their own responsibility and tend to be independent when they have autonomy in themselves. Therefore, the role of the teacher was only as a facilitator, a guider, and a lighter when applying collaborative activity within a group in the learning process. however, if the Col was applied well in grouped learning, then the objectives in the learning will be carried out well, even the results obtained can be satisfactory. Meanwhile, teacher $C$ said that the existence of this paired learning in literature learning makes students indirectly understand the existence of independence in taking the initiative The next step in learning. This made the student learn to make an autonomous-decisions on his or her partner.

Question 5: what was the benefit of the Community of Inquiry?

Teacher A told that Col was a good strategy for the students. This framework could develop not just involving the cognitive part of the student, but also their social aspect where they 
could collaborate with other people, they could share their thoughts with other people. On the other hand, teacher B state that Col in language learning has many benefits. one of them was the formation of the character of student independence in learning. In addition, the existence of social interactions caused students' communication skills with foreign languages to be well felt. Moreover, the benefit of this Col based on Teacher C's perspective was the students could make their own decisions. one of the abilities captured by teachers was when they discuss the storyline of a story. students expressed their own point of view, but in the end, they found the same meeting point.

\subsection{The Result of the Students' Interview}

Prior to a better perspective and understanding, the researcher conducted students' interviews. This interview aimed to know the students' point of view about implementing Col in the group activity. It uses a close-ended question and open-ended question to gain better results. By involving 10 students (3 students from class 7 Malakas, 3 students from class 7 Maganda, and 4 students from class 8 Matapat) the results of this interview are shown in table 1 and figure 2.

Table 1. The result of the Students' Interview

\begin{tabular}{clccccc}
\hline No & Question & Yes & No & \multicolumn{2}{c}{ Total } \\
\hline 1 & & $\Sigma$ & $\%$ & $\Sigma$ & $\%$ & $\%$ \\
\hline 2 & My English Teacher often used group or pair activities & 10 & 100 & 0 & 0 & 100 \\
\hline 3 & Group activity made my communication skill better & 8 & 80 & 2 & 20 & 100 \\
\hline 4 & Group activity helped me gain my independent learning & 8 & 80 & 2 & 20 & 100 \\
\hline 5 & I liked group/pair activity rather than individual activity & 8 & 80 & 2 & 20 & 100 \\
\hline
\end{tabular}

Several cognitive resources were also used by the students while the group activity was conducted. The result is on the chart.

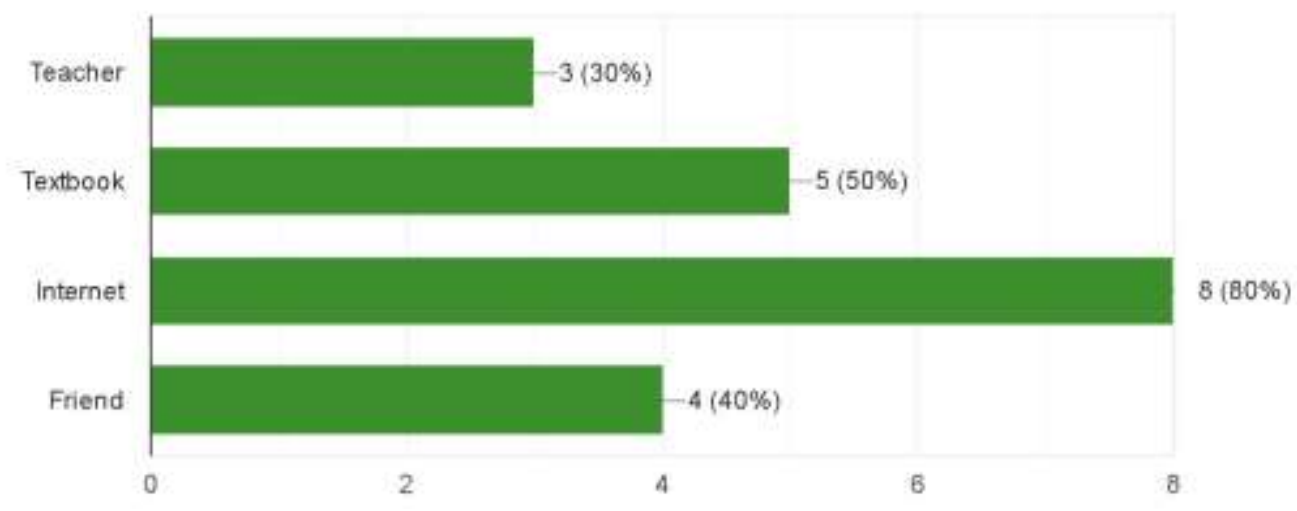

Figure 2. The result of students' cognitive resources

Based on the data above, 3 students from 10 students stated that teacher was the resource of knowledge while group/pair activity was conducted. Half of the students choosed the textbook as the resource of cognitive presence. Most of the students (80\%) said that the internet is the source of cognitive presence and 4 students (40\%) stated that they ask their friends and admit them as the resource of knowledge. 
Furthermore, the researcher also asked the student about their perspective about the group activity which contains the $\mathrm{Col}$ in it. The researcher found heterogenous answers. Most of them (80\%) were very interested and joyful when the group/pair activity has occurred. They said that group activity helps them know the characteristic of each other or even group activity made them got their confidence to communicate with the English language. This was one of the ways to improve my speaking skill. Unluckily, there were several students (20\%) were disagree with the group activity. They said that it felt difficult to focus when they did the task together. Sometimes, they felt really shy to do such a discussion together with other students. They did not comfortable when doing exercise with someone else.

\section{Discussion}

\subsection{The Implementation of Community of Inquiry through Students' Group Activity}

In a truly collaborative learning experience, the nature of the communication between and among the participants poses functional challenges of considerable complexity (Garrison, 2016). Therefore, research would discuss the community of inquiry approach concerning selfregulation, communication activity, and motivation in a learning environment named as students' autonomous ability, using theoretical frameworks such as building collaborative learning communities and group activity. Based on the Col framework made by Garrison et al. (2000), the Col framework that was applied in classes 7 and 8 of Pangasinan State University (PSU) Integrated School High School, Philippines is as presented in figure 3.

Based on the observation, the group activity technique was utilized at almost the whole of English Language learning activity. Group activity was used to enhance students' ability to solve the problem/task given by the teacher, to communicate with each other, and to have critical thinking as stated in the Col approach goal. When group activity was conducted, the teacher was only a facilitator to guide students to reach the goal of study. The teacher at PSU High School also often used group activities for the students in English Language learning because the center of knowledge is not always the teacher, but it could come from others. By grouping them means teacher, facilitates them to communicate in the English Language. As the result, Col existed in English Language learning especially when the students worked in a group.

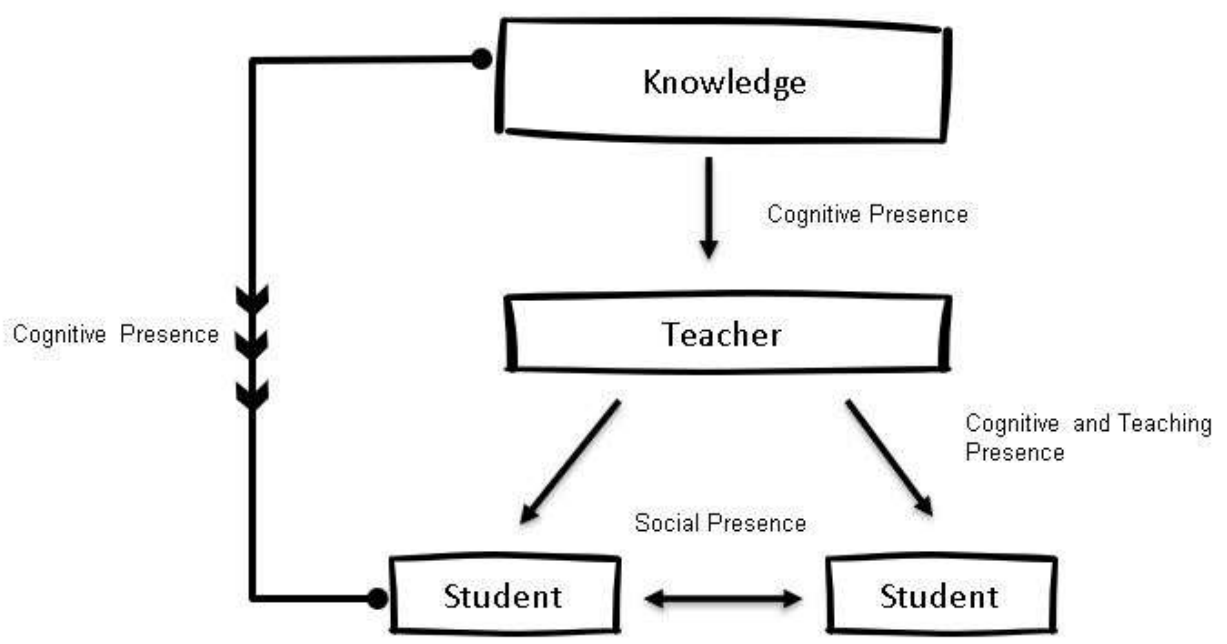

Figure 3. The Community of Inquiry Approach Adopted and elaborated from (Garrison et al., 2000). 
According to the researcher's observation, Col was implemented in English learning activity during teaching practice as well as when the school teachers were teaching. Group or collaborative learning activities were activities that suited the Col approach with the presence of cognitive, teacher presence, and social presence. as mentioned, this learning pattern was the learning pattern most often used by teachers there. As mentioned above, Col was a brief and representative framework that defines a collaborative and positive approach to thought and learning (Garrison, 2016).

When collaborative activity in English Language learning was applied, three main presences were very influential in group activities. Based on research findings, cognitive presence was found not only through books but also from other group members. By creating group activities, the students would exchange their thoughts and their understanding with others. Indirectly, English proficiency in speaking would also be better trained. It was where cognitive presence through existing resources was very influential in student learning

Table 2. Community of Inquiry Coding Template

\begin{tabular}{|c|c|c|c|}
\hline & Categories & Indicators & Sentences \\
\hline \multirow[t]{4}{*}{ Cognitive Presence } & Triggering event & Sense of Puzzlement & "It is a random word..." \\
\hline & Exploration & Information Exchange & $\begin{array}{l}\text { "What kind of sentences it } \\
\text { is?" }\end{array}$ \\
\hline & Integration & Connecting Ideas & $\begin{array}{l}\text { "There are } 2 \text { verbs here, } \\
\text { maybe it is complex } \\
\text { sentences..." }\end{array}$ \\
\hline & Resolutions & Apply new ideas & $\begin{array}{l}\text { "Let's arrange these } \\
\text { words.." }\end{array}$ \\
\hline \multirow[t]{3}{*}{ Social Presence } & Emotional Expression & Emotion & $\begin{array}{l}\text { "Our group should be the } \\
\text { first one who finished this } \\
\text { task..." }\end{array}$ \\
\hline & Open Communication & Risk-free expression & $\begin{array}{l}\text { Who knows the strategies } \\
\text { to finish this task?" }\end{array}$ \\
\hline & Group Cohesion & $\begin{array}{l}\text { Encouraging } \\
\text { Collaboration }\end{array}$ & $\begin{array}{l}\text { "Let's work together, } \\
\text { guys..." }\end{array}$ \\
\hline \multirow[t]{3}{*}{ Teaching presence } & $\begin{array}{l}\text { Instructional } \\
\text { Management }\end{array}$ & $\begin{array}{l}\text { Defining and initiating } \\
\text { discussion topics }\end{array}$ & $\begin{array}{l}\text { "why this sentence called a } \\
\text { complex sentence?" }\end{array}$ \\
\hline & Building Understanding & $\begin{array}{l}\text { Sharing personal } \\
\text { meaning }\end{array}$ & $\begin{array}{l}\text { "by a group activity, you will } \\
\text { find the solutions together } \\
\text { with your friends in a } \\
\text { group.." }\end{array}$ \\
\hline & Direct Instruction & Focusing discussion & $\begin{array}{l}\text { "Group A, you all better } \\
\text { divide the tasks, so you can } \\
\text { do it effectively.." }\end{array}$ \\
\hline
\end{tabular}

The ability to use language in real life was indispensable when students learn a language. This was where the ability of social presence would work. Based on the research interview, the teachers let the students communicate and collaborate to find their autonomous learning without the attendance of the teacher. The students remind, cooperate, and exchange knowledge with each other through the activities provided. However, some students did not have the same level of confidence. Therefore, the teacher should be more active in guiding them. 
In terms of directing, based on interviews, teachers were merely facilitators in this community learning. When the student was having trouble completing the assignment, the instructor stepped in as an interpreter and tutor. Teachers might also be a source of information and experience for their students. Nevertheless, since the development of trust in language learning was so important, teachers should supervise them from afar.

\subsection{Students' Autonomous}

Based on the interview, Col through group collaborative activity in PSU High School had been implemented by all teachers. However, not all students could adjust to the group's activities. Based on the teacher's experience in teaching, not all children had the independence to learn because each of them had his/her own character. It was where the role of the teacher was needed. The teacher should be able to guide and direct the student to have a responsibility in completing the task.

Collaborative work in group activities that were not conducive because of character distinctions could result in even less interaction between students and could reduce with less social and cognitive presence. When some students were excluded from group activities, they might learn less and enjoy themselves less. At the same time, the other members of the group miss out on the benefits of communicating with the person who was excluded (s). For example, if excluded group members were less skilled at the task at hand, the other members of the group miss out on peer tutoring opportunities that would have been available if everyone had been included. (Jacobs \& Shan, 2015). Moreover, their confidence would decrease and lead to a lack of communication skills in English as well as grammar practice in everyday conversation.

Teachers at PSU strongly believe that in the language of Learning, confidence and selfreliance in students were very important. It was also supported by the use of technology in English. Even though researchers had clarified the meaning and concept of autonomy over the last few decades, autonomous Language learning strategies had evolved in tandem with technological advancements. Language teachers had used new technologies as tools to help them deliver lessons throughout history. Learners quickly adopted the innovations that were first used in teaching as part of their independent language learning activities(Murray et al., 2017). Fundamentally, the purpose of English learning was students could communicate in English both passively and actively, and to express it requires high confidence and independence

Until now, the Col approach conducted through group activities was considered appropriate for language teaching activities in higher education students. Teachers also felt that the framework of Col helps teachers to create more effective learning concepts. Col is judged not only to provide cognitive intelligence to students but also to provide much-needed social intelligence in language learning. with these two elements, the student's autonomy would slowly form.

\section{Conclusion}

Collaborative work in a group activity is used to enhance students' ability to solve the task, to communicate with each other, and to have critical thinking as same as the Col approach goal. According to the researcher's data, Col was implemented in English learning activity during teaching practice as well as when the school teachers are teaching. Three main presences are 
very influential in group activities. cognitive presence was found not only through books but also from other group members. By creating group activities, students will exchange their thoughts and knowledge.

Because each child has his/her own personality, not all students have the ability to learn independently. Some students may learn less and enjoy themselves less if they are excluded from group activities. Col is thought to offer students with not only cognitive intelligence but also much-needed social intelligence in language learning. The student's autonomy will gradually emerge as a result of these two factors. Until today, the Col approach has been thought to be effective in language teaching activities for students in higher education. The goal of English learning is for students to be able to communicate both passively and actively in English.

\section{References}

Ardi, P. (2007). Enhancing Students' Learning Autonomy Through The Collaborative AudioJournal Project in Listening Comprehension III. Sanata Dharma University, 19461102.

Arnó-Macià, E. (2016). Learner Autonomy and Awareness Through Distance Collaborative Group Work in English for Academic Purposes. Springer International Publishing Switzerland. https://doi.org/10.1007/978-3-319-40956-6

Cao, N. T. (2011). Challenges of Learning English in Australia towards Students Coming from Selected Southeast Asian Countries: Vietnam, Thailand and Indonesia. International Education Studies, 4(1), 13-20.

Choi, Y. H., \& Lee, H. W. (2008). Current Trends and Issues in English Language Education in Asia. In The Journal of Asia Tefl (Vol. 5, Issue 2).

Feri, Z. O., \& Erlinda, R. (2012). Building Students' Learning Autonomy through Collaborative Learning to Develop Their Language Awareness. 518-523.

Gall, Joyce P. Gall, Meredith Damien. Borg, W. R. (2014). Applying Educational Research. In Pearson Education Limited.

Garrison, D. R. (2011). Online Community of Inquiry Review: Social, Cognitive, and Teaching Presence Issues. University of Calgary. https://doi.org/10.1128/JB.05513-11

Garrison, D. R., Anderson, T., \& Archer, W. (2010). The First Decade of the Community of Inquiry Framework: A Retrospective. Internet and Higher Education, 13(1-2), 5-9. https://doi.org/10.1016/j.iheduc.2009.10.003

Garrison, R. (2016). Thinking Collaboratively (Vol. 53, Issue 9). Routledge Taylor \& Francis Group. https://doi.org/10.1017/CBO9781107415324.004

Garrison, R., Anderson, T., \& Archer, W. (2000). Critical Inquiry in a Text-Based Environment. The Internet and Higher Education, 2(2), 87-105.

Ginting, D. (2017). Promoting Students' Autonomy Through The Indonesian Massive Open Online Course. Proceedings of the 15th Asia TEFL and 64th TEFLIN International Conference 2017.

Goldberg, J., \& Welsh, K. M. (2009). Community and inquiry: Journey of a science teacher. Cultural Studies of Science Education, 4(3), 713-732. https://doi.org/10.1007/s11422-0099176-7

Jacobs, G. M., \& Shan, T. H. (2015). Advancing Learner Autonomy in EFL Via Collaborative Learning. 7th International Conference on Teaching English as Foreign Language (COTEFL). 
Kilis, S., \& Yıldırım, Z. (2018). Investigation of Community of Inquiry Framework in Regard to Self-Regulation, Metacognition and Motivation. Computers and Education, 126, 53-64. https://doi.org/10.1016/j.compedu.2018.06.032

Madalińska-Michalak, J., \& Bavli, B. (2018). Challenges in Teaching English as A Foreign Language at Schools in Poland and Turkey. European Journal of Teacher Education, 41(5), 688-706. https://doi.org/10.1080/02619768.2018.1531125

Mohd Noor, K. B. (2008). Case Study: A Strategic Research Methodology. American Journal of Applied Sciences, 5(11), 1602-1604.

Murray, G., Gao, X. (Andy), \& Lamb, and T. (2017). Motivation and Autonomy in Learning English as Foreign Language: A Case Study of Ecuadorian College Students. English Language Teaching, 10(2), 100. https://doi.org/10.5539/elt.v10n2p100

Pokhrel, S. (2016). Learner Autonomy: A Western Hegemony in English Language Teaching to Enhance Students' Learning for Non-Western Cultural Context. Journal of NELTA, 21(1-2), 128-139. https://doi.org/10.3126/nelta.v21i1-2.20209

Preece, A. S. D., \& Bularafa, M. W. (2015). Community of inquiry method and language skills acquisition: Empirical evidence. Journal of Education and Practice, 6(27), 89-93.

Shea, P., \& Bidjerano, T. (2009). Community of Inquiry as A Theoretical Framework to Foster "Epistemic Engagement" and "Cognitive Presence" in Online Education. Computers and Education, 52(3), 543-553. https://doi.org/10.1016/j.compedu.2008.10.007

Šimenc, M. (2008). The Status of The Subject in The Classroom Community of Inquiry. Theory and Research in Education, 6(3), 323-336. https://doi.org/10.1177/1477878508095587

Valizadeh, M. (2016). Iranian EFL Students' Emotional Intelligence and Autonomy in Distance Education. English Language Teaching, 9(10), 22. https://doi.org/10.5539/elt.vgn1op22 